\title{
Analysis of Brazilian scientific production in Orofacial Motricity
}

\author{
Antonio Lucas Ferreira Feitosa ${ }^{1}$ \\ https://orcid.org/0000-0003-0143-3927 \\ Gabriel Trevizani Depolli \\ https://orcid.org/0000-0001-6969-1418 \\ Roberta Lopes de Castro Martinelli ${ }^{3}$ \\ https://orcid.org/0000-0002-5791-2575 \\ Marisa Siqueira Brandão Canuto 4 \\ https://orcid.org/0000-0002-0559-1212
}

Centro Integrado de Saúde Amaury de Medeiros - CISAM-UPE, Recife, Pernambuco, Brasil.

Universidade Federal do Espírito Santo UFES, Vitória, Espirito Santo, Brasil.

${ }^{3}$ Centro de Especialização em Fonoaudiologia Clínica - CEFAC, São Paulo, São Paulo, Brasil.

Universidade Estadual de Ciências da Saúde de Alagoas - UNCISAL, Maceió, Alagoas, Brasil.

Conflict of interests: Nonexistent

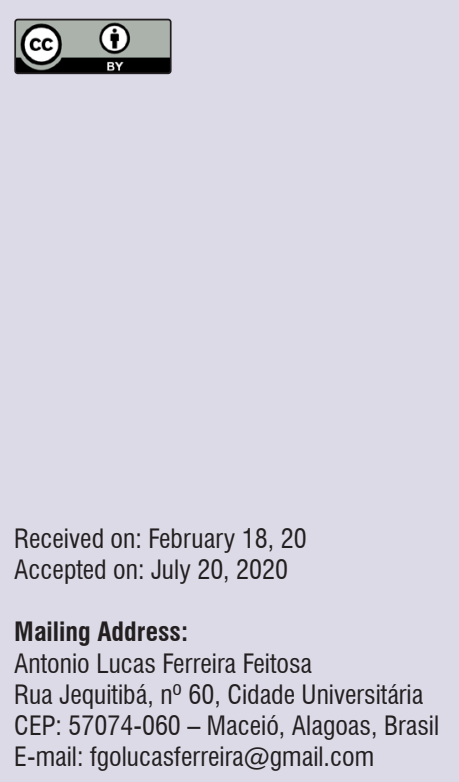

\section{ABSTRACT}

Objective: to analyze the Brazilian scientific production in Orofacial Motricity from the annals of Brazilian congresses and journals in the field of Speech Therapy in the last six years.

Methods: for this bibliometric review, data related to the year of production, type of study, Brazilian region/State, modality of higher education institution, event/magazine and presentation format were considered and tabulated. The data were discussed from the perspective of quantitative and representative values.

Results: 1,299 studies have been published in the past six years. The highest production was achieved in 2014 and there was a predominance of original studies. Public higher education institutions produced more studies when compared to private ones. The event with the largest number of publications was the Brazilian Congress on Speech, Language and Hearing Sciences, and the journal with the largest number of publications was CEFAC Journal. The Southeast region was predominant in publications, followed by the Northeast region.

Conclusion: the characterization of scientific production in orofacial motricity allowed us to verify that this is a consolidated area of activity, although it still requires advances.

Keywords: Speech, Language and Hearing Sciences; Scientific Publication Indicators; Brazil 


\section{INTRODUCTION}

The regulation of speech therapy as a profession boosted the categorization of studies about human communication and its disturbances, defining specific areas $^{1}$, among them: Orofacial Motricity (OM), a specialty which focuses on the study, research, prevention, diagnosis and treatment of the miofunctional orofacial system, as well as breathing, suction, mastication, swallowing and speaking functions. The creation of the Scientific Committee of Orofacial Motricity in the Brazilian Speech Therapy Society, as well as, the inauguration of the Brazilian Association of Orofacial Motricity (BAOM) provided the gathering of professionals in this field of work for the research in the area $^{2}$.

In 2002, the first analysis of scientific material about OM was published, having considered the time period of 1970 to 2000 , showing the increase in the number of material along the years in this area. The analysis also showed that the Brazilian research about the theme reflected aspects like anamneses, diagnosis and treatment, in detriment of etiologic factors ${ }^{3}$.

Another published research in 2009 performed a new gathering of data equivalent to the period from 2000 to 2005 in all areas of speech therapy, demonstrating that the published researches on OM corresponded to $11.3 \%$ of the total, the third area with the biggest amount of scientific material, developing studies reaching children, teenagers and adults, however, with predominant emphasis in diagnosis and intervention of orofacial disturbances ${ }^{4}$.

Following the suppositions of previous studies, in 2016, some authors developed another scientific data in the OM area, corresponding to the years from 2005 to 2015 , a more extensive period, allowing the identification of a significant growth. The authors identified that $14 \%$ of the scientific production in journals corresponds to the OM area, being $73.5 \%$ studies of the original type. There were no changes about themes along the years, because the area still presented the same fragility of previous years about prevalence and diagnostic aspects, and a low percentage of therapyfocused work $(6.8 \%)^{5}$.

Some authors describe that the foundation of clinical and social applications have origins in the scientific production ${ }^{2}$. Thus, developing studies about the current scientific production contributes to the identification of profile for the researchers and in produced studies in the area. Thus, the analysis of scientific literature in the $\mathrm{OM}$ area favors the way for future research publications, because it allows the knowledge of the expansion or reduction in the number of studies, generating hypotheses for this occurrence and providing possible answers for actions that can improve the scope in the last years.

Based on what was exposed, this study aimed to analyze the Brazilian scientific production in Orofacial Motricity in the records of conferences and Brazilian journals in the area of speech therapy in the last six years.

\section{METHODS}

Exploratory-descriptive and bibliometric revision study ${ }^{6}$, without the need of approval of ethics committee on research. The full available records were analyzed from the websites of the events from the Brazilian Congress on Speech, Language and Hearing Sciences $(\mathrm{CBFa})^{7}$, Bauru Speech Therapy Congress $(\mathrm{COFAB})^{8}$ and the Brazilian meeting of Orofacial Motricity (EBMO) ${ }^{9}$ referring to the last six editions. The open access volumes of Brazilian journals were also analyzed within the area of speech therapy: CEFAC Magazine - Speech, Language, Hearing Sciences and Education Journal ${ }^{10}$, Communication Disorders, Audiology and Swallowing (CoDAS) ${ }^{11}$, Communication Disturbance $^{12}$ and Audiology Communication Research $(A C R)^{13}$ published in the last six years (2014-2019). All data were collected online independently by two researchers. After collecting, the researchers paired the performed searches to verify any discrepancies in the data. A third evaluator was contacted to intercede in case of disagreement.

The bibliographic search was performed during the months of April and December of 2019. All the works found in the websites of the events with published records in the following categories: posters, prize contestants, thesis and dissertations, as well as, oral communications were included in the review. Incomplete, not fully available and non-related studies were excluded. From the journals only complete original works, integrative revision, systematic revision, case report and experience report were included. Announcements, editorials, editor's letter and reviews were excluded. The analyzed variables were: year, type of study (systematic review, integrative review, original study, case report and experience report), region and state from Brazil, type of university (IES) (public and private), event/journal and format of presentation (simple abstract, extended or full article). 
For the extraction of variables related to the region and state of Brazil, as well as, the type of university, the study felt necessary to access the Lattes curriculum within the Lattes platform, a department of the National Council for scientific and technology $(\mathrm{CNPq})^{14}$ because in some editions of the events CBFa, COFAB e EBMO, there were no signatures of attendance from the authors in the records. A manual and individual search for the name of the first and second author within each available work in the records; if not found, the search was done using the title of the work. School affiliation was considered as the one in which the author was affiliated during the period when the event was held. The region and state were associated to the school affiliation of the author.

The data were organized in spreadsheets in Microsoft Excel 2016, and later transformed into charts for better comprehension of data. The data analysis used the descriptive analytic method by means of formulas from the Excel software itself, considering the absolute values ( $n$ ) and relatives (\%) for each variable. The data were presented by six charts.

\section{LITERATURE REVIEW}

\section{Search results:}

1,299 studies were published in the last six years in the OM area. The year of $2014(21.9 \%, \mathrm{n}=285)$ and $2015(19.6 \%, n=251)$ presented the biggest number of scientific production within the area. The year of $2016(13.1 \%, n=167)$ verified the smallest scientific production in the last six years, according to what can be observed in Chart 1.

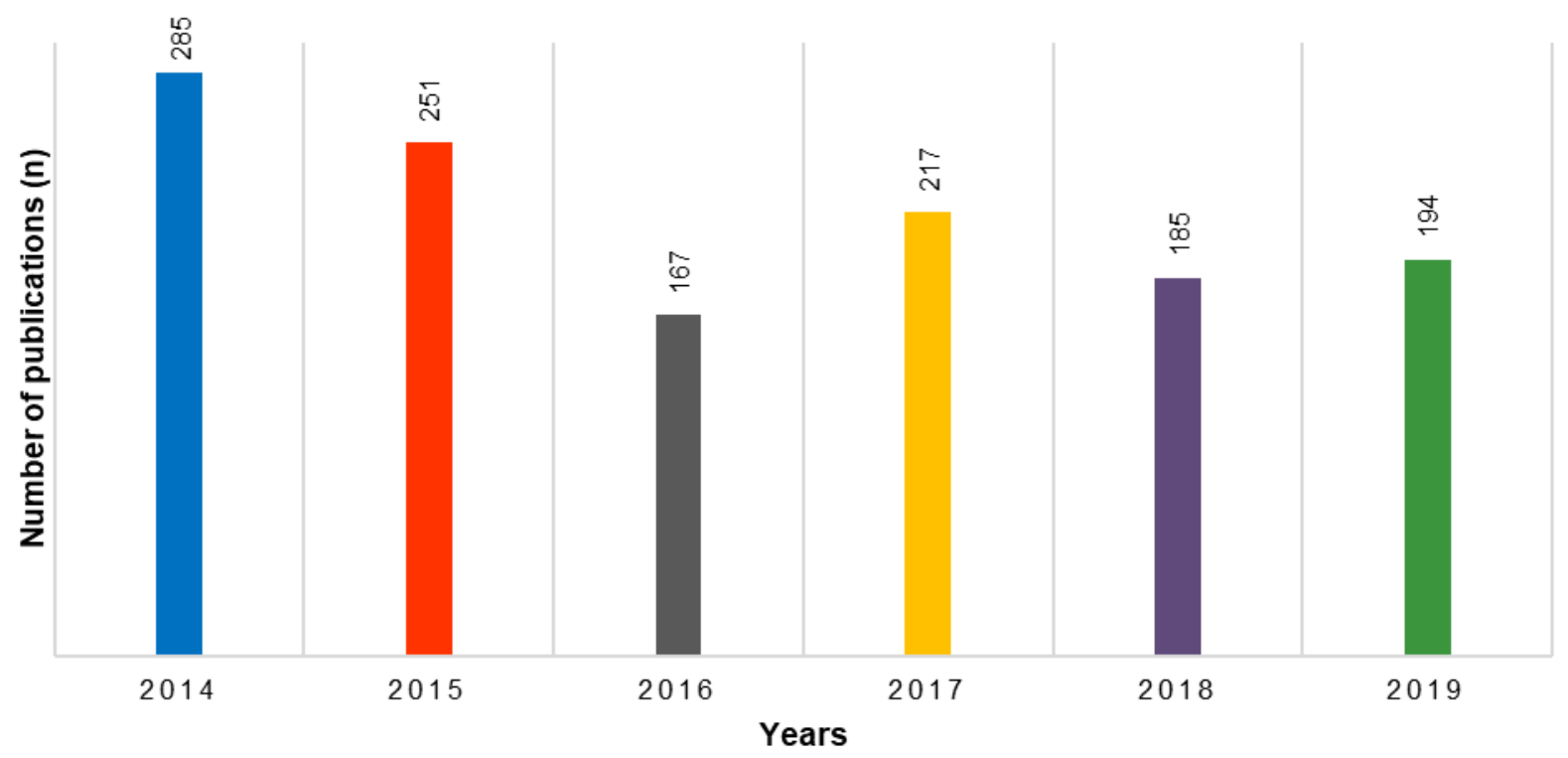

Figure 1. Number of scientific publications on Orofacial Motricity in recent years (2014-2019)

About the type of published studies in the area, a predominance of original studies was observed $(n=203)$ followed by case reports $(n=33)$ with a highlight to the year of 2014 and systematic revisions $(n=31)$ in the year of 2015. Experience reports represented the smallest percentage among all the other kinds of studies, 2016 being the year with the smallest number $(n=2)$ according to the data shown in Chart 2.
Considering the type of institutions (Chart 3 ), the public institutions represented $80.1 \%(n=1,040)$ of all national literature in the $\mathrm{OM}$ area, with a highlight to the year of $2014(n=232)$ and $2015(n=202)$. For the private institutions, there was little variation over the years, and in 2018 , this particular production fell $50 \%$ (Chart 3 ). 


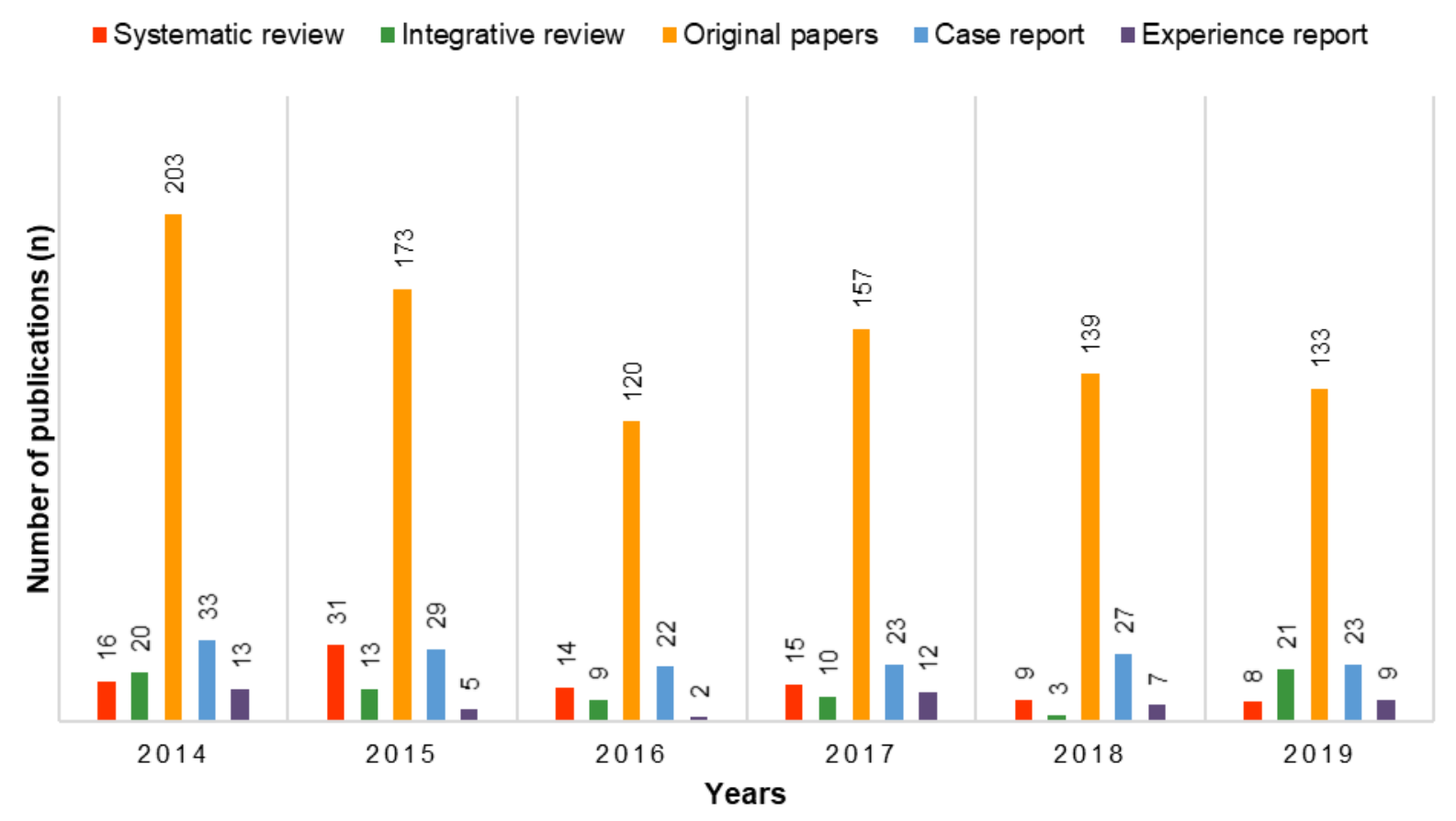

Figure 2. Types of studies published on Orofacial Motricity in recent years (2014-2019)

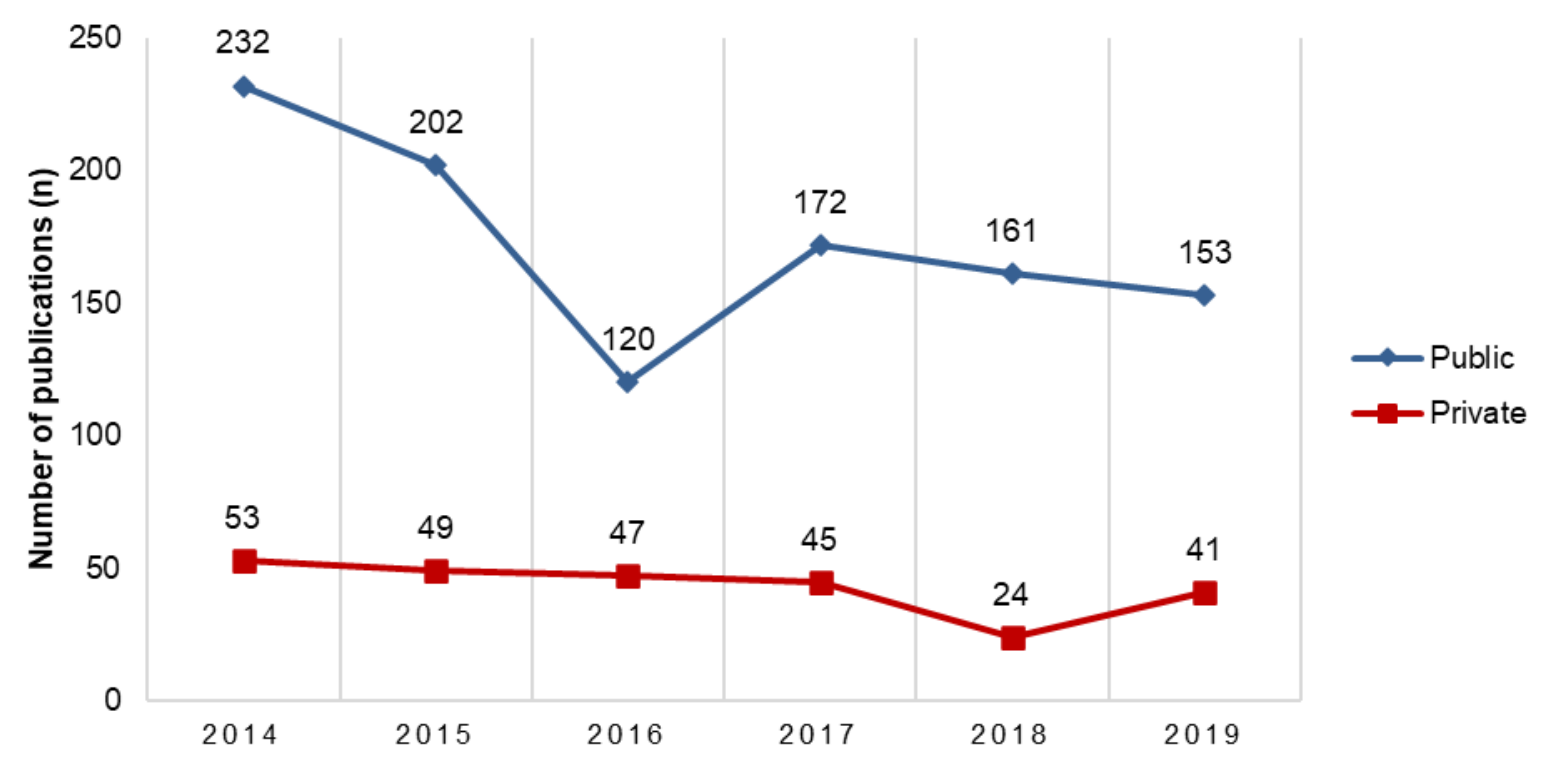

Figure 3. Scientific production according to the modality of the Higher Education Institution of the authors in recent years (2014-2019)

In the analysis of scientific events, the biggest highlight was the CBFa which published 457 scientific works in the area $(35.2 \%, n=457)$ with highlight to the year $2014(n=136)$. EBMO was the second event with $436(33.6 \%, n=436)$ published studies in the records, 2017 being the year $(n=98)$ with the biggest scientific production, as shown in Chart 4.
Among the four journals evaluated, the CEFAC journal overcame the others, with 140 publications (10.8\%, $n=140), 2015$ being the year with most publications $(n=40)$, although a decrease in the quantity of articles in the area was observed in the following years, as shown in Chart 4. The journal Distúrbios da Comunicação presented the smallest percentage of studies in the OM area $(2.3 \%, n=30)$. 


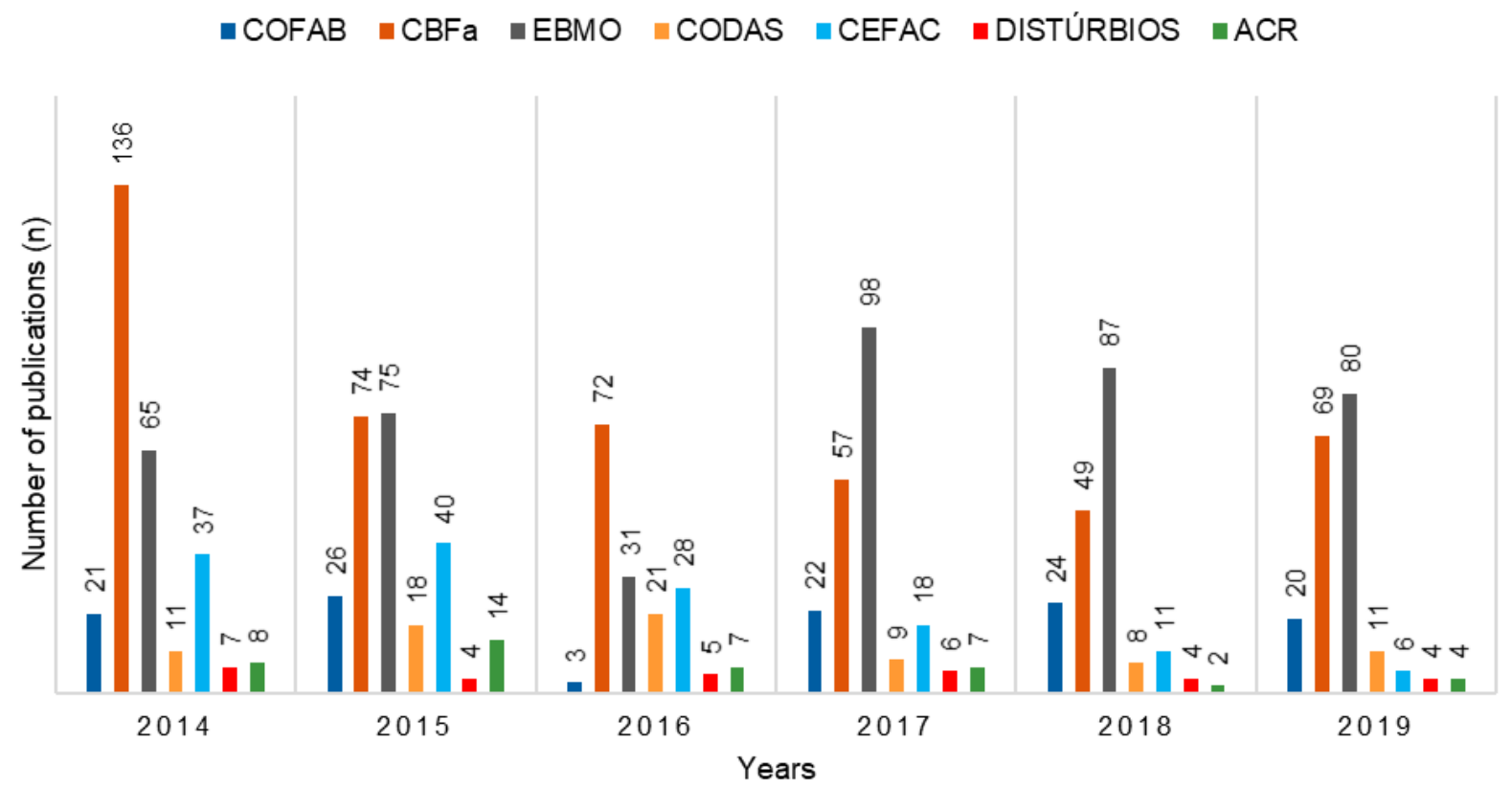

Captions: COFAB: Bauru Speech Therapy Congress; CBFa: Brazilian Congress on Speech, Language and Hearing Sciences; EBMO: Brazilian meeting of Orofacial Motricity; CEFAC: Revista CEFAC; DISTÚRBIOS: Communication Disorders Journal; ACR: Audiology - Communication Research

Figure 4. Scientific events and journals in the field of Speech Therapy which have published the most in recent years (2014-2019)

The national events published 809 (62.3\%) simple abridgements, with highlight to the year $2014(n=193)$ and 290 (22.3\%) full published articles in journals, 2015 being the year with most prevalence $(n=76)$, as shown in Chart 5.

Among Brazilian regions, the Southeast concentrated $48.5 \% \quad(n=630)$ of publications, São Paulo (SP) $(36 \%)$ being the state with most representation $(n=468)$, followed by Minas Gerais $(8.4 \%, n=109)$. The Northeast $(29.6 \%)$ was the second region of the country with the biggest scientific production in the OM area, Pernambuco $(12 \%, n=156)$ being the state with biggest contribution, followed by Paraíba $(7.4 \%, n=96)$ according to the data in Chart 6 . The Northern region presented the smallest attendance $(n=9)$ with less than $1 \%$.

\section{- Scientific article $\quad$ Extended abstract $\quad$ Simple abstract}

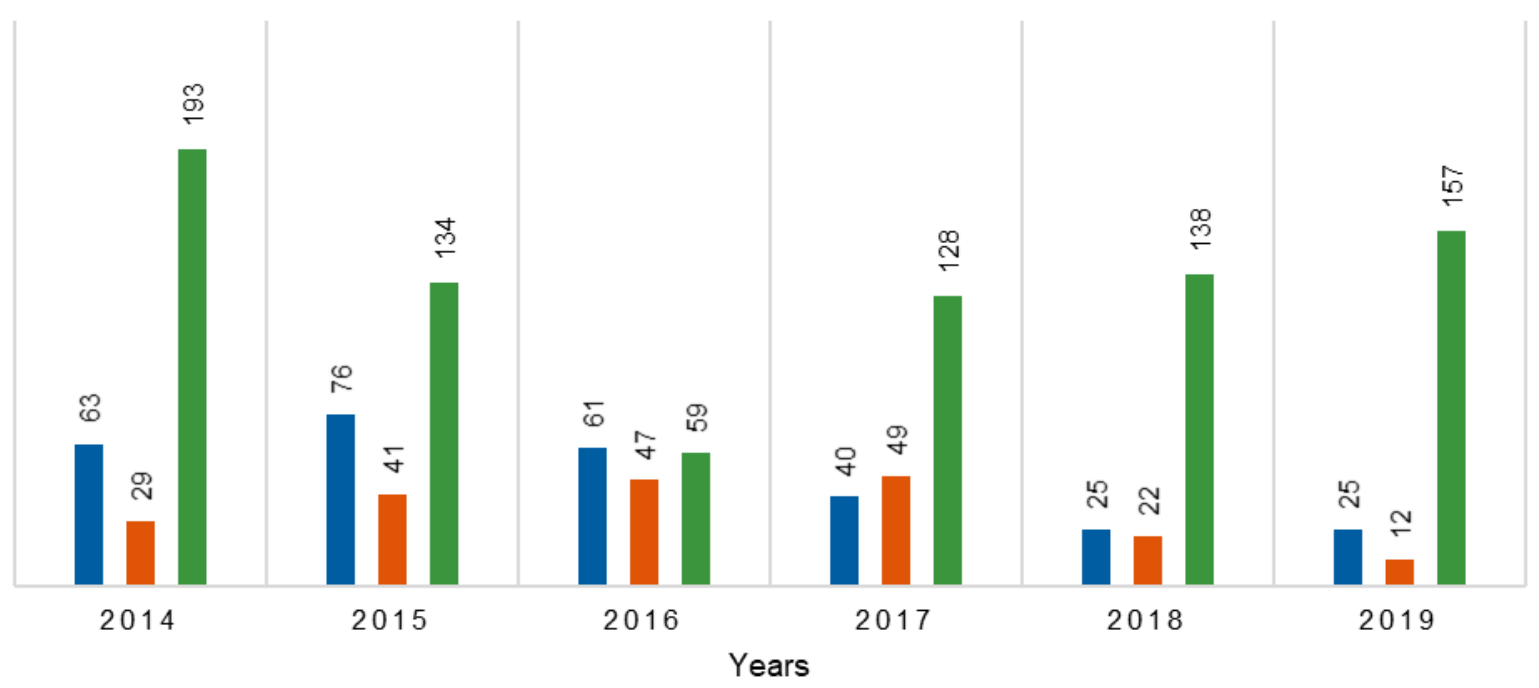

Figure 5. Presentation format of scientific production on Orofacial Motricity in recent years (2014-2019) 


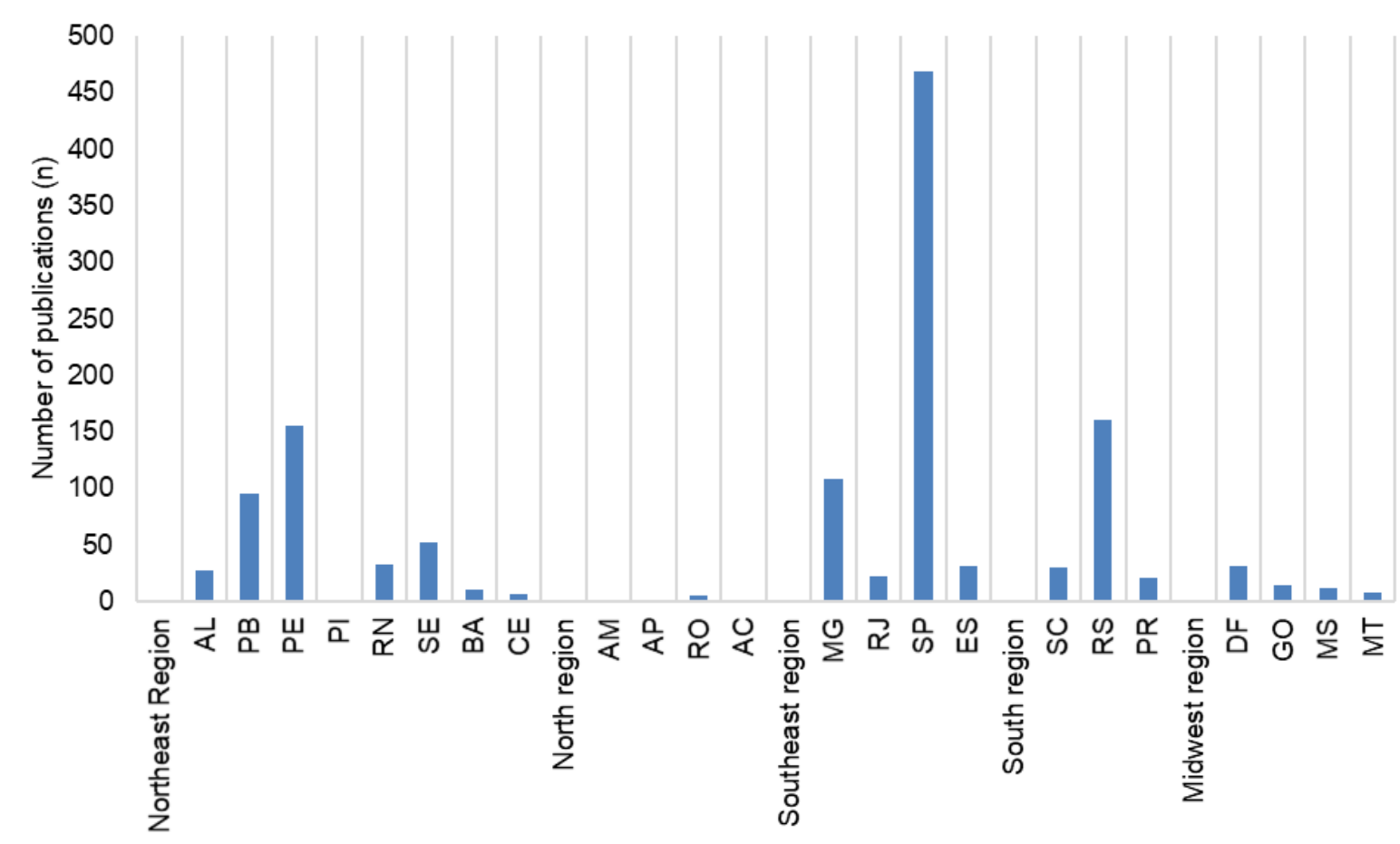

Captions: AL-Alagoas; PB-Paraíba; PE-Pernambuco; PI-Piauí; RN-Rio Grande do Norte; SE-Sergipe; BA-Bahia; CE-Ceará; AM-Amazonas; AP-Amapá; R0-Rôndonia; AC-Acre; MG-Minas Gerais; RJ-Rio de Janeiro; SP-São Paulo; ES-Espírito Santo; SC-Santa Catarina; RS-Rio Grande do Sul; PR-Paraná; DF-Distrito Federal; GO-Goiás; MS-Mato Grosso do Sul; MT-Mato Grosso.

Figure 6. Distribution of publications on Orofacial Motricity according to Brazilian regions and states

\section{Analysis of selected studies}

Considering the published studies, 2014 was the year that received the biggest highlight, although a decrease of publication was observed in the following years. It's hard to declare objectively which factors would be the reason for this decrease in the number of publications within the $\mathrm{OM}$ area. However, it's supposed that the location of the EBMO and CBFa that year, held in southeastern states of Brazil, a region, in which, according to CBFa data ${ }^{15}$, there are 1,632 specialists in the area, can be a cause for the considerable increase of recorded publications that year.

About types of studies, original works tend to be more frequent, because they reflect the interest of researchers in the speech therapy field to seek scientific evidence, elaborating studies, whether by means of a master's orientation, doctorate, scientific initiation or by means of research groups. Consequently, a predominance of original studies is more reflected than any others.

The "case report" type study, for providing isolated information of the state of an individual, brings a great contribution for the scientific community from a clinical standpoint ${ }^{16}$. However, the publication in some journals have been restrict, because they are found in the base of pyramid, indicating little scientific evidence ${ }^{17}$. Maybe, that's why, the number of publications of this kind of study is more prevalent in scientific events than in journals.

Another relevant data in this study is the predominance of systematic revision (SR) over integrative revision (IR). The SRs are important for theory foundation of researches and even for professional clinic decisions ${ }^{18,19}$. They are considered the highest level of evidence when meta-analysis is added ${ }^{20,21}$ for verification of effectiveness in interventions performed by means of randomized clinical essays ${ }^{21}$. Unlike the IRSs, a method that uses different types of studies, such as, non-experimental and experimental ${ }^{22}$, but that also possess significant contributions, when performed with excelence ${ }^{23}$. In spite of the predominance of SRs over IRs, the number still presents itself insufficient to fortify scientific evidence for OM. Because of the importance of this kind of study, the necessity of revisions is highlighted due to excellence standards such as Cochrane Handbook ${ }^{24}$ or the PRISMA recommendation (Main items to report systematic revisions and meta-analysis) ${ }^{25,26}$.

Experience reports produced less often (3.7\%) in OM. Perhaps, students are more prepared and oriented 
for the elaboration of original articles, expecting bigger chances of publication and bigger scientific relevance for literature. It is necessary to investigate the reason for this number to be so reduced in Brazilian Orofacial Motricity and boost students, professionals and professors to publish their experiences, since they bring contributions to clinical practice.

According to the Web of Science Group, approximately $60 \%$ of Brazilian scientific productions are performed in public universities ${ }^{27}$, corroborating the findings of this study, in which it is possible to observe the number of publications in the public and private universities. Every year, the publications originated by private schooling institutions were stable and inferior to the number of publications from public institutions, showing a drop of $40 \%$ of studies in the year 2018 . Another relevant point to infer this data, is related to the fact of public institutions which offer the speech therapy course, concentrate the biggest number of masters and doctors in the area of the study ${ }^{28,29}$, as well as, the researchers with productivity sponsorships by the National Council of Scientific and Technological Development (CNPq). In a brief research performed by CNPq, 47 of 54 sponsored researchers are teachers in public universities, factor that makes the high attendance evident in this type of institution ${ }^{30}$.

Comparing the publications between the events, in the last three years, we can observe a bigger predominance of publications in EBMO, presenting a total of 436 presented studies in total. This may be due to the event being more specific to the OM area. However, the SBFa conference presents the biggest number of works in the last years $(n=457)$, the OM area occupying third place, according to a 2019 study ${ }^{31}$. Supposed that the number of presented studies in EBMO and the SBFa conference remains the same, over two years, the Brazilian Gathering of OM would overcome the number of works presented in the CBFa. There are factors, which also influence this number, for example, date, place and even the subscription price between the two events.

Concerning journals, the CEFAC journal presented predominance of scientific publications in the country within the OM area, which corroborates with studies already performed about the scientific production of $\mathrm{OM}^{3,5}$ being overcome by the CoDAS only in 2019. It's worth mentioning that the CEFAC journal, being a publication associated to ABRAMO, presents itself as a strong vehicle in the field of OM.
Every year, the number of simple published abridgements, when compared to the number of publications of articles and extended abstracts, is a highlight. The elevated number of this kind of study can be explained by selected cuts of the original studies and even due to the ease of writing it, considering the events, usually, allow abridgments of a maximum of 500 words, which facilitates in its elaboration. Another factor that can influence the reduced number of complete articles is the complexity of its writing, with a higher demand of theory foundation and excellence of the technical writing, factors that may not be present in the academic graduation of many speech therapists and college students ${ }^{16,31,32}$.

The state of São Paulo presented the biggest number of publications about Orofacial Motricity in the country. This difference, compared to the remaining states, may be due to some factors such as the presence of bigger public universities, a bigger number of productivitysponsored researchers from CNPq (39 to 54) ${ }^{30}$ and the concentration of the biggest number of masters in the speech therapy area. The second region with a highlight was the Northeast of the country, currently with 21 public institutions, which was responsible for over $30 \%$ of publications in the country, highlighting the states of Pernambuco and Paraíba, both concentrating the two most important master's degrees in the area, as well as, CNPq researchers in the OM area (1, in total $)^{30}$, a factor that influences directly the percentage of publications compared to the remaining states of the region.

Another data of importance is the reduced number of publications in the Northern region of the country. According to information obtained through the websites of the Brazilian Federal Council of Speech Therapy and Audiology ${ }^{33}$ and the ministry of education (MEC) $)^{34}$, the region possesses only 11 registered speech therapy courses. Meanwhile, the southeast region of the country possesses 29 speech therapy courses. This suggests that the number of publications can be related to the number of college institutions per region, a hypothesis raised by this study. If we consider the number of institutions, we can observe that the state of Alagoas, which only has one institution with the speech therapy course, produced approximately $2 \%$ more than the four Northern states of Brazil. This fact suggests the accomplishment of studies that show the real reason for the low representation of the $\mathrm{OM}$ area in the Northern part of the country ${ }^{35}$.

The present study has limitations such as the restriction of selecting only events, which possessed 
scientific records, and editing time. However, this study showed the current landscape of OM publications, suggesting new researches that investigate the causes associated to the data found, as well as, the reasons for the observed discrepancies, which will bring benefits to the practice and scientific research in this area.

\section{CONCLUSION}

The year of 2014 had the biggest number of publications in the Orofacial Motricity in the last six years and there was a decline in production over the last years. The public institutions are the ones that most produced scientific work within the area, in its majority, original studies yielded by researchers from the southeastern region. Most publications occurred in the Brazilian Congress on Speech, Language and Hearing Sciences, in the simple abridged form, and in the CEFAC journal.

\section{REFERENCES}

1. Brasil. Lei no. 6965, de 09 de dezembro de 1981. Dispõe Sobre a Regulamentação da Profissão de Fonoaudiólogo, e determina outras providências. Diário Oficial da União $10 \mathrm{dez}$ 1981; p. 23333. Disponível em: http://www.fonoaudiologia.org.br/ ccfa/index.php/historia-da-fonoaudiologia/.

2. Marchesan IQ, Duarte LIM. Histórico e áreas de domínio da motricidade orofacial no Brasil. In: Silva HJ, Tessitore A, Motta AR, Cunha DA, Berretin-Felix G, Marchesan IQ (orgs). Tratado de Motricidade Orofacial. São Paulo: Editora Pulso; 2019. p.37-44.

3. Alves MRM. A produção fonoaudiológica nacional em Motricidade Orofacial - 1970 a 2000 [Dissertação]. Curitiba (PR): Universidade Tuiuti do Paraná, Mestrado em Distúrbios da Comunicação Humana; 2002.

4. Berberian AP, Ferreira LP, Corteletti LCBJ, Azevedo JBM, Marques JM. A produção do conhecimento em distúrbios da comunicação: análise de periódicos (2000-2005). Rev. Soc. Bras. 2009;14(2):153-9.

5. Tomaz-Morais J, de Lima JAS, Luckwü-Lucena BT, Batista AUD, Limeira RRT, Silva SM et al. Integral analysis of Brazilian scientific production in Orofacial Myology: state of art and future perspectives. Rev. CEFAC. 2016;18(2):520-32.

6. Chueke GV, Amatucci M. O que é bibliometria? Uma introdução ao Fórum. Internext. 2015;10(2):1-5.

7. Sociedade Brasileira de Fonoaudiologia (SBFa). Congressos. São Paulo, 2019 [Acesso em: 20 maio. 2019]. Disponível em: https://www.sbfa.org. br/portal2017/congressos.

8. Congresso Fonoaudiológico De Bauru (COFAB). Edições Anteriores. Bauru, 2019. [Acesso em: 20 mai 2019]. Disponível em: http://www.cofab.fob. usp.br/anais/.

9. Associação Brasileira De Motricidade Orofacial (ABRAMO). Anais dos Encontros de MO. Campinas, 2019. [Acesso em 10 mar 2019]. Disponível em: http://www.abramofono.com.br/ index.php/encontros-m-o/.

10. Revista CEFAC. Edições Anteriores. São Paulo, 2019 [acesso em: 30 abr 2019]. Disponível em: http://www.scielo.br/scielo.php?script $=$ sci issues \&pid=1516-1846\&lng $=$ pt\&nrm $=$ iso.

11. Communication Disorders, Audiology And Swallowing (CoDAS). Acervo. São Paulo, 2019. [Acesso em: 20 mai 2019]. Disponível em: http:// www.codas. periodikos.com.br/archive.

12. Distúrbios da Comunicação. Anteriores. São Paulo, 2019. [Acesso em: 10 mai 2019]. Disponível em: https://revistas.pucsp.br/dic/issue/archive.

13. Audiology - Communication Research (ACR). Números: todos. São Paulo, 2019. [Acesso em: 25 mai 2019] Disponível em: http://www.scielo. $\mathrm{br} /$ scielo. php? script $=$ sci_issues $\&$ pid $=2317$ $6431 \&$ lng $=$ pt\&nrm =iso.

14. Conselho Nacional de Desenvolvimento Científico e Tecnológico - CNPq. Brasília: Ministério da Ciência, Tecnologia e Inovação, 2019. Disponível em: http://lattes.cnpq.br/. Acesso em: 26 dez 201

15. Conselho Federal de Fonoaudiologia [homepage na internet]. Consulta especialistas por especialidade/UF [acesso em 30 abr 2020]. Disponível em: https://www.fonoaudiologia.org.br/ cffa/

16. Cáceres AM, Gândara JP, Puglisi ML. Scientific writing and the quality of papers: towards a higher impact. J Soc Bras Fonoaudiol. 2011;23(4):401-6.

17. Vandenbroucke JP. Case reports in an evidencebased world. J R Soc Med. 1999;92(4):159-63.

18. Gontijo B, Rocha DM, Flor EM. Relatos de caso: seu papel em um periódico médico. An Bras Dermatol. 2008;83(6):561-5.

19. Sampaio RF, Mancini MC. Estudos de revisão sistemática: um guia para síntese criteriosa da evidência científica. Rev Bras Fisioter. 2007;11(1):83-9. 
20. Donato $H$, Donato $M$. Etapas na condução de uma revisão sistemática. Acta Med Port. 2019;32(3):227-35.

21. Cook DJ, Guyatt GH, Laupacis A, Sackett DL, Goldberg RJ. Clinical recommendations using levels of evidence for antithrombotic agents. Chest. 1995;108(4):227-30.

22. Souza MT, Silva M, Carvalho R. Revisão integrativa: o que é e como fazer. Einstein. 2010;8(1):102-6.

23. Soares CB, Hoga LAK, Peduzzi M, Sangaleti C, Yonekua T, Silva DRAD. Revisão integrativa: conceitos e métodos utilizados na enfermagem. Rev Esc Enferm USP. 2014;48(2):335-45.

24. Higgins J, Green S. (2011). Cochrane Handbook for Systematic Reviews of Interventions Version 5.1.0. Available from: www.handbook.cochrane.org (accessed February 12, 2019).

25. Liberati A, Altman DG, Tetzlaff J, Mulrow C, Gotzsche PC, loannidis JP et al. The PRISMA statement for reporting systematic reviews and meta-analyses of studies that evaluate health care interventions: explanation and elaboration. PLoS Med. 2009;6(7):1-28.

26. Moher D, Liberati A, Tetzlaff J, Altman DG. Preferred reporting items for systematic reviews and meta-analyses: the PRISMA statement. Ann Intern Med. 2009;151(4):264-9.

27. Web of Science Group. Research in Brazil: Funding excellence: Analysis prepared on behalf of CAPES by the Web of Science Group. Clarivate Analytics. 2019.

28. Paz-Oliveira A, Carmo MP, Ferreira LP. Brazilian doctors in speech-language pathology and audiology certificated in the period 2009-2013: profile of training. Rev. CEFAC. 2015;17(2):586-94.

29. Ferreira LP, Ferraz PRR, Garcia ACO, Falcão ARG, Ragusa-Mouradian CA, Herrero $E$ et al. Speechlanguage therapists with Ph.D. in Brazil: profile from 1976 to 2017. CoDAS. 2019;31(5):1-8.

30. Conselho Nacional de Desenvolvimento Científico e Tecnológico - CNPq. Bolsas e Auxílios. Brasília: Ministério da Ciência, Tecnologia e Inovação, 2019. Disponível em: http://lattes.cnpq.br/. Acesso em: 26 dez 2019.

31. Seno MP, Capellini SA. Brazilian Congress on Speech, Language and Hearing Sciences: history, organization and scientific production. Rev. CEFAC. 2019;21(1):1-12.
32. Alves MF, Moura LOBM. A escrita de artigo acadêmico na universidade: autoria x plágio. Ilha do Desterro. 2016;69(3):77-93.

33. Conselho Federal de Fonoaudiologia [homepage na internet]. Ensino Superior [acesso em $23 \mathrm{dez}$ 2019]. Disponível em: https://www.fonoaudiologia. org.br/cffa/.

34. Brasil, Ministério da Educação [homepage na internet]. Sistema de Regulação do Ensino Superior. Cadastro Nacional de Cursos e Instituições de Educação Superior [acesso em 23 dez 2019]. Disponível em: http://emec.mec.gov.br

35. Brasil BC, Gomes E, Teixeira MRF. O ensino de fonoaudiologia no Brasil: retrato dos cursos de graduação. Trab Educ Saúde. 2019;17(3):1-19. 